\title{
The HSN and the Netherlands Indies: Challenge and Promise
}

\section{By Ulbe Bosma}

To cite this article: Bosma, U. (2021). The HSN and the Netherlands Indies: Challenge and Promise. Historical Life Course Studies, 10, 41-45. https://doi.org/10.51964/hlcs9565

\section{HISTORICAL LIFE COURSE STUDIES}

Not Like Everybody Else.

Essays in Honor of Kees Mandemakers

VOLUME 10, SPECIAL ISSUE 3

2021

GUEST EDITORS

Hilde Bras

Jan Kok

Richard L. Zijdeman 


\section{HISTORICAL LIFE COURSE STUDIES}

Historical Life Course Studies is the electronic journal of the European Historical Population Samples Network (EHPSNet). The journal is the primary publishing outlet for research involved in the conversion of existing European and nonEuropean large historical demographic databases into a common format, the Intermediate Data Structure, and for studies based on these databases. The journal publishes both methodological and substantive research articles.

\section{Methodological Articles}

This section includes methodological articles that describe all forms of data handling involving large historical databases, including extensive descriptions of new or existing databases, syntax, algorithms and extraction programs. Authors are encouraged to share their syntaxes, applications and other forms of software presented in their article, if pertinent, on the openjournals website.

\section{Research articles}

This section includes substantive articles reporting the results of comparative longitudinal studies that are demographic and historical in nature, and that are based on micro-data from large historical databases.

Historical Life Course Studies is a no-fee double-blind, peer-reviewed open-access journal supported by the European Science Foundation (ESF, http://www.esf.org), the Scientific Research Network of Historical Demography (FWO Flanders, http://www.historicaldemography.be) and the International Institute of Social History Amsterdam (IISH, http://socialhistory.org/). Manuscripts are reviewed by the editors, members of the editorial and scientific boards, and by external reviewers. All journal content is freely available on the internet at https://openjournals.nl/index.php/hlcs.

\section{Co-Editors-In-Chief:}

Paul Puschmann (Radboud University) \& Luciana Quaranta (Lund University)

hislives@kuleuven.be

The European Science Foundation (ESF) provides a platform for its Member Organisations to advance science and explore new directions for research at the European level. Established in 1974 as an independent non-governmental organisation, the ESF currently serves 78 Member Organisations across 30 countries. EHPS-Net is an ESF Research Networking Programme.

The European Historical Population Samples Network (EHPS-net) brings together scholars to create a common format for databases containing non-aggregated information on persons, families and households. The aim is to form an integrated and joint interface between many European and non-European databases to stimulate comparative research on the micro-level.

Visit: http://www.ehps-net.eu.
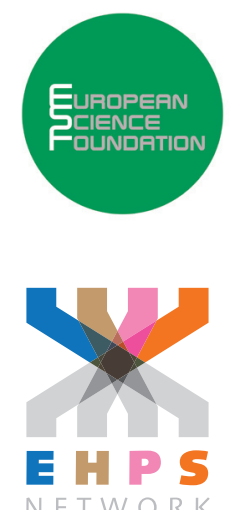


\title{
The HSN and the Netherlands Indies: Challenge and Promise
}

\author{
Ulbe Bosma \\ International Institute of Social History, Amsterdam \& VU Amsterdam
}

\begin{abstract}
In 2000 Kees Mandemakers and I started a project to trace the life courses of Dutch migrants to the Netherlands Indies. This article describes the process of data collection, the research questions and the project's main findings that have been published in various articles and a monograph. Two conclusions stand out: the first pertains to the heavily urban provenance of this migration and the second emphasizes the relatively educated and skilled background of colonial Dutch migration. This second finding contradicts earlier assumptions about the Dutch colonies as a place where undesirable elements were shovelled off. The current article further discusses findings of projects on Swiss and Luxembourger military migrations to the Netherlands Indies. An important difference between Dutch military migrants and those from other European countries regards the role of their service within a life course. While Dutch colonial military service was often the first step to make a career in colonial Indonesia, for Europeans from abroad it was rather a move of desperation as well as an attempt to earn some money that would enable them to start a business and a family in their country of birth. Their migration experience was rather a 'life cycle' migration. The article finally describes attempts to extend the HSN to the Dutch citizens born in the Netherlands Indies.
\end{abstract}

Keywords: HSN, Colonial Indonesia, Migrants, Soldiers, Life cycle migration

e-ISSN: $\quad$ 2352-6343

DOI article: https://doi.org/10.51964/hlcs9565

The article can be downloaded from here.

(C) 2021, Bosma

This open-access work is licensed under a Creative Commons Attribution 4.0 International License, which permits use, reproduction \& distribution in any medium for non-commercial purposes, provided the original author(s) and source are given credit. See http://creativecommons.org/licenses/. 


\section{INTRODUCTION}

Over the past decades the HSN has spun an ever thickening web of information about life courses of Dutch people. Moreover, through links with other large databases we now have tools for doing history in ways unthinkable thirty years ago. My contribution to this special issue is not about advanced linking of data but on a rather old school project. One of the particular challenges of the HSN was to find and trace people who were born in the Netherlands but moved abroad. It is known that about 250,000 emigrated to the United States and roughly 300,000 to the Netherlands Indies over the period covered by the HSN. These were just the largest groups, as many others went to a number of European countries, Latin America and South Africa. In terms of life courses these migrants are a particularly interesting group as they share social capital with their siblings and to a slightly lesser extent with their neighbours while their life experiences developed so differently. Why did these people leave and what may explain their decisions to migrate?

\section{THE MIGRATION TO THE NETHERLANDS INDIES PROJECT}

Exactly twenty years ago these questions came up in the canteen of the IISH, the place where many new research projects were born. The head of the research department at the time, Jan Lucassen, Kees Mandemakers and I decided that we would try to conduct a research into this large group of Dutch imperial migrants, the so-called 'Indiëgangers', a project that was to receive the acronym MNI (Migration to the Netherlands Indies). I wrote myself in this project as a postdoc and after it received funding from the Dutch Science Foundation, I worked with Kees and his HSN team to collect the necessary data. While preparing the application it was already clear to me that we had embarked on a genuine 'searching for the needle in the haystack operation', but we had some prior knowledge. First, thanks to the work of Martin Bossenbroek we knew that about 154,000 military had been recruited for the Netherlands Indies between the 1815 and 1909 of whom an estimated 110,000 were Dutch (Bossenbroek, 1992). Over the entire HSN cohorts (born between 1812 and 1922) about 130,000 individuals left for the Netherlands Indies in uniform. We also knew that another 26,000 left after having been enlisted in the colonial civil service. Yet we lacked information on the numbers of other migrants who performed a wide range of professions in the semi-governmental and private sector; from teacher to plantation boss. Through the MNI project, we found out that this last category must at least have comprised 50,000 individuals in the 19th and 90,000 in the 20th century.

Thanks to diligent colonial and military clerks, basic data on the civil service and military careers are all preserved in the so-called military and civil service enrolment files. However, nothing was digitized at the time that the research project was underway. The name lists providing access to the regimental rolls of the military personnel came available as scans, but they were handwritten and not yet machine readable, whereas the indices of personnel files of the colonial civil service were only available in a spotty and blurred printing. The scans of the military name lists had to be visually compared and validated using birth date, place and mother's name. For the civil servants, only after an arduous manual correction job, the scans could be automatically compared with the HSN data. The most time-consuming part of the data gathering concerned data about private persons, who started a career in the Netherlands Indies outside the government or the army. We knew that permissions had to be obtained by every private person who wished to settle in the Netherlands Indies between 1819 and 1870. About 7,000 of these permissions were found and they provided precious information about origins and occupations. ${ }^{1}$ After comparing the result of months of work on these files, only eleven of these individuals were also found to be part of the HSN.

Fortunately, not all people were so difficult to find. Particularly important in this regard were the 'persoonskaarten' (personal cards), that are preserved of all Dutch people who died after 1939. Since practically all Dutch people who were born after 1890 and survived the Second World War - and not to forget the violence during the Indonesian War of Independence raging between 1945 and 1949 — returned to the Netherlands, the persoonskaarten provide a good coverage for the later colonial period. Finally, data from the civil registration in some cases mention migration to the Dutch Netherlands East Indies.

A major handicap has been the absence of a systematic collection of civil registration data for the Europeans in the Netherlands Indies that could be compared with the HSN, and which would have been particularly helpful to trace Dutch civilians who arrived in the Netherlands Indies in the late 19th century, a category

1 iisg.amsterdam/hsn/projects/mni 
neither covered by the permissions of entrance nor by the persoonskaarten. We also have gaps in our data about civilians who came to the Netherlands Indies in the 20th century and who died there. However, there are data of the Red Cross on the deceased in the Japanese internment camps and in the POW camps, where 10 respectively $30 \%$ of all interned succumbed. These lists were not examined, because they were not yet available fifteen years ago. Indeed, after twenty years there is still work to do, but the data we did obtain provide a remarkable coverage of the Dutch persons who arrived in the Netherlands Indies. In 2007, the total number of persons identified as migrants at the Netherlands Indies stood at 723 (for a comprehensive description of these data see Bosma \& Mandemakers, 2008).

In 2007, Kees Mandemakers and I were able to make our first reconstruction of the social and geographical background of the so called Indiëgangers. For the first time, we were also able to present reliable estimates of the total number of Dutch who did leave for the Netherlands Indies. These were obviously still conservative figures that have gone up slightly over the past thirteen years when more migrants to the Netherlands Indies were traced. Yet we could conclude in 2007 during the first half of the 19th century that about $0.8 \%$ of all Dutch who had reached at least the age of sixteen made the passage to the Dutch East Indies. This figure increased to almost $2.5 \%$ in the early 20th century. In other words, at that time one in every forty Dutch persons who reached the age of sixteen embarked for this huge Dutch colony and subsequently almost every Dutch person had family and/or friends there. We could also establish the gender balance which was still heavily male-biased in the 19th century, however not because women did not travel to the Netherlands Indies. Actually, they migrated in larger numbers than we expected in the 19th century and gender parity was almost achieved in the 20th century. This gender bias was the obvious consequence of 19th-century colonial migration being an overwhelmingly military affair. Finally, with regard to the numbers, we could establish that the migration to the Netherlands Indies was quantitatively even more important than Dutch migration to the United States. Economically and culturally this migration was the livestream or the human metabolism of the Dutch empire, which was unveiled in incredible detail thanks to the HSN. We could now assess how migrants to the Netherlands compared in terms of geographics, social background or family composition and history with those who stayed at home.

An important feature of colonial migration is its predominantly urban character. Those who were born in one of the Dutch four big cities (Amsterdam, Rotterdam, The Hague and Utrecht) were twice as likely to end up in the Netherlands Indies compared to those whose cradle stood in municipalities with less than 5,000 inhabitants. This presents exactly the mirror image of the migration to the United States, which was overwhelmingly rural. The most unexpected finding of the MNI project unequivocally discarded the myth that the Dutch colonies were a place to which rascals were shovelled off to. The non-military migration of the Dutch bourgeoisie (high civil servants, high ranking military and wealthy merchants) were widely overrepresented. Positions in the colonial bureaucracy and also leading positions in private enterprise were reserved for the sons of the Dutch elite. Of the Dutch-born civil servants in Indonesia, $90 \%$ had completed a higher vocational or university training. Of course, the rank and file of the migrants to the Netherlands Indies came from more humble stock, but it does not justify the 'gutter of Europe' as the colloquial name for recruitment garrison of the colonial army in Harderwijk. Many of the young Dutch colonial soldiers came from an educated labour class and an educated lower middle class background. The corollary of this is that the true urban proletarians were underrepresented, which seems hard to believe but can be explained by considering the recruitment criteria for the colonial army, which included a minimum height and a clean criminal record. Urban poverty reduced the height of many boys under the required 1,57 meter and the same social misery pushed young people to illicit behaviour and the existing class-based judicial system guaranteed a criminal record for even the pettiest of crimes (Bosma, 2010, p. 34).

The question why Dutch young men joined the colonial army is particularly intriguing, given that in the early 19th century they had an $80 \%$ chance of finding their grave somewhere in the immense archipelago. Part of the answer is that quite a few of these recruits were veterans whose only trade was soldiering. It is also known that in the early 19th century almost a third of them embarked for the East after having been offered colonial service as an alternative to punishment. Active recruiting in the urban environment may have led many desperate youngsters to take a handsome amount of money, hoping that their future would be less dismal than the stories they had heard about young men who never returned, their bodies left behind in some hardly penetrable jungle. In the course of the 19th century survival chances increased substantially, however. The army became an avenue for upward mobility to begin within its own ranks, as about 30\% of the soldiers left the army in the rank of corporal, sergeant and a few even as officer. From 1870 onwards soldiers were allowed to stay in the Netherlands Indies after having served their term, and in these very years the colonial economy offered increasing opportunities for a career in government or plantation enterprise. What we see, thanks to our HSN-MNI sample, is that enlisting in the colonial army became a route for 
people with a decent education but with no money to try their luck in the Netherlands Indies. We find violinists, carpenters and shoemakers boarding transport ships heading to the Netherlands Indies.

Thanks to the HSN we can in principle answer the question whether migrants to the Netherlands Indies did defy the self-fulfilling prophecy that whoever is born for a dime, will never be worth a quarter. We are still working on this question, but there is evidence that the colonial army did offer significant opportunities for upward mobility as the cadre consisted predominantly of Dutchmen, whereas for Indonesians there was no chance to reach a rank higher than sergeant until the 20th century. Also, remunerations and pension of the Dutch colonial army were definitely competitive on the Dutch labour market. Another indication is that from the late 19th century onwards a rapidly growing number of soldiers sought and found a job in colonial society.

\section{INTERNATIONAL COMPARISONS AND FURTHER RESEARCH}

The MNI project has not only made an important contribution to Dutch imperial history; it has also triggered comparative work in Luxembourg and Switzerland, countries that provided the Dutch colonial army with 1,075 and 5,800 soldiers, respectively. ${ }^{2}$ Luxembourg - a tiny country that shared its monarch with the Dutch nation until 1890 - saw a relatively large number of young men leaving for the Dutch colonial army. In the 1870 s $1.75 \%$ of the Luxembourger young men left for the Netherlands Indies, percentage-wise more than from the Netherlands itself. This was the result of intensive recruitment efforts during the fearsome Aceh War that began in 1873. Much like the Dutch soldiers they did come from an urban environment and from modest or even humble but not from the poorest strata and often they had acquired some professional skills. In a joint article, Thomas Kolnberger and I concluded that Luxembourger veterans in the Dutch colonial army were less inclined to stay in the Netherlands Indies after receiving their passport back and that on average they served shorter tours than their Dutch counterparts (see Bosma \& Kolnberger, 2017). Yet the Luxembourgers with professional background or artisanal skills were more likely than their average fellow nationals to try their luck in colonial society after having served in the army.

We hardly find highly trained professionals such as medical doctors among the Luxembourgers in the Dutch colonial army. This is in contrast to the Germans, who by the mid-19th century made up half of the army medical corps, as Teichfisher has demonstrated (Teichfischer, 2016). Still, most of the Germans, and probably Belgian and Swiss soldiers as well, considered their military stint in the Netherlands Indies as 'life cycle' migration to escape poverty and hoped to return with some money to start their own business and family. Some achieved their mission, but many did not. Swiss soldiers in the Netherlands Indies, for instance, complained bitterly about their conditions and one contingent even unchained a mutiny. What becomes clear from Krauer's article on the recruiment of Swiss for the Dutch colonial army is that crimping practices and deceit were effectively employed during the Aceh War, when substantial Swiss cohorts arrived in Batavia to the utter dismay of the Swiss consul in the colonial capital Batavia (Krauer, 2019, pp. 131 and 137).

The various research projects conducted so far suggest that with the exception of the German doctors, prospects for foreign volunteers who enlisted in the Dutch colonial army were far more grim than for the Dutch, who had better career opportunities and were better informed about the atrocities during the Aceh War. The Dutch youngsters were happy to let the Belgians, Germans, Swiss and Luxembourger do the fighting and the dying in the 1870s, but they came in larger number in the final decade of the 19th century when conditions in the army as well as survival chances improved rapidly (Bossenbroek, 1992, p. 279).

While the 'Indies' branch of the HSN offers great material for comparative imperial history, the micro sociological methods of the HSN may also allow us to say more about the intergenerational mobility within the huge Dutch imperial migration circuit. In 1937, when travel between the Netherlands and the Dutch East Indies had reached a peak, almost 40,000 people made the journey between the motherland and the colony or vice versa. In The Hague alone, 30,000 people resided who were born in the Netherlands Indies in the 1930s. This migration circuit was both instrumental in maintaining colonial rule and an avenue for upward generational social mobility. Since many participants in this circuit are not covered by the HSN but are definitively part of the Dutch social history, Kees Mandemakers and I have taken steps to create a Netherlands Indies counterpart of the HSN. There is already a sample model retrieved from the colonial 
Government Almanac which contains excerpts from the Civil Registration of Europeans. Unfortunately, any further advance had to be postponed when we stumbled upon great difficulties in accessing the Civil Registration files which are spread over Indonesia, and although they are partly microfilmed by the Church of the Latter Day Saints, these films are often of wanting quality, as interns of Radboud University who worked on this pilot project discovered. We are looking forward to a systematic collection effort of the European civil registration of colonial Indonesia that would enable us to pull this project off.

\section{REFERENCES}

Bosma, U. (2010). Indiëgangers. Verhalen van Nederlanders die naar Indië trokken. Amsterdam: Bert Bakker. Bosma, U., \& Kolnberger, T. (2017). Military migrants: Luxembourgers in the colonial army of the Dutch East Indies. Itinerario, 41(3), 555-580. doi: 10.1017/S0165115317000687

Bosma, U., \& Mandemakers, K. (2008). Indiëgangers: Sociale herkomst en migratiemotieven (1830-1950). Een onderzoek op basis van de Historische Steekproef Nederlandse bevolking (HSN). BMGN - Low Countries Historical Review, 123(2), 162-184. doi: 10.18352/bmgn-Ichr.6779

Bossenbroek, M. P. (1992). Volk voor Indië: De werving van Europese militairen voor de Nederlandse koloniale dienst, 1814-1909. Amsterdam: Van Soeren.

Krauer, P. (2019). Welcome to Hotel Helvetia! Friedrich Wüthrich's illicit mercenary trade network for the Dutch East Indies, 1858-1890. BMGN - Low Countries Historical Review, 134(3), 122-147. doi: 10.18352/bmgn-Ichr.10740

Teichfischer, P. (2016). Transnational entanglements in colonial medicine: German medical practitioners as members of the health service in the Dutch East Indies (1816-1884). Histoire, médecine et santé, 10, 63-78. doi: 10.4000/hms.1035 